REVISTA DE LITERATURA E CULTURA RUSSA

\title{
"O divã de tia Sônia”, um conto de Mikhail Kuzmin
}

\section{"Aunt Sonya's Sofa", a short story from Mikhail Kuzmin}

Autor: Yuri Martins de Oliveira Universidade de São Paulo, São Paulo, São Paulo, Brasil Edição: RUS Vol. 12. No 20

Publicação: Dezembro de 2021 DOI: https://doi.org/10.11606/issn.2317-4765.rus.2021.191513 


\section{"O divã de tia \\ Sônia”, um conto de Mikhail Kuzmin}

\section{Yuri de Oliveira Martins*}

Resumo: Tradução para o português brasileiro do conto "O divã de tia Sônia" (Кушетка тёти Сони), do escritor Mikhail A. Kuzmin (18721936), precedida por uma breve nota introdutória a respeito do texto e do processo de tradução. Primeiro escritor russo a tratar da homossexualidade em seus textos, a prosa de Kuzmin tem sido pouco estudada e traduzida.

\begin{abstract}
Translation in Brazilian Portuguese of the short story "Aunt Sonya's Sofa" (Кушетка тёти Сони), by Mikhail A. Kuzmin (1872-1936), preceded by a brief introduction, which aims to present the text and to comment the translation. As the first Russian writer to deal with homosexuality in his texts, Kuzmin's prose has been little studied and translated.
\end{abstract}

Palavras-chave: Kuzmin; Conto; Literatura russa; Literatura \& homossexualidade; Tradução

Keywords: Kuzmin; Short story; Russian literature; Literature \& homosexuality; Translation 


\section{Nota Introdutória}

"A prosa de Kuzmin ainda não entrou em uso

- tanto mais interessante falar sobre ela".

B. EIKENBAUM (1920) ${ }^{1}$
* Mestre em Letras pelo Programa de Pós-Graduação em Literatura e Cultura Russa da Faculdade de Filosofia, Letras e Ciências Humanas da Universidade de São Paulo (FFLCH/USP); https://orcid. org/0000-0002-2697-3906; yuri. martinsz@gmail.com.

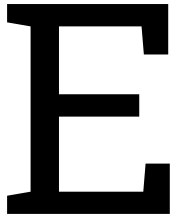

scrito em 1907 e publicado originalmente na revista literária Vesý, o conto "O divã de tia Sônia" nos apresenta a família Gambakov e seus conflitos, tendo como narrador um dos móveis da antessala, o divã. Ou, melhor, "a" divã, já que o objeto tem uma voz narrativa feminina no original russo. Depois de passar sessenta anos em um depósito, por supostamente trazer má sorte à família, "a" divã é trazida de volta para o convívio familiar. Dividido em sete pequenas partes mais ou menos interligadas, a estrutura do conto lembra uma peça de teatro: cada parte é como uma cena, com começo, meio e fim, com as personagens entrando e saindo da antessala onde se encontra nossa divã-narradora. Essa limitação espacial acaba se tornando, também, uma limitação do que se sabe a respeito da história: como só temos acesso ao que se passa na antessala, o conto muitas vezes se torna um jogo de "dito pelo não dito", com insinuações das personagens, de um lado, e as deduções de quem lê, por outro.

A família Gambakov, de origem nobre, é formada por Maksim Petróvitch, um velho general; Kóstia, seu filho e estudante universitário; Nástia, sua filha e aluna de instituto; e Pavla Petróvna, sua irmã solteirona. O conto se desenrola a partir de um conflito de gerações (tema, aliás, marcante na literatura

1 EIKHEMBAUM, B. О прозе М. Кузмина [Da prosa de M. Kuzmin]. In: EIKHEMBAUM, B. 0 литературе [Da literatura]. Moscou: Sov. Pissátel', 1987[1920], p. 348. 
russa) ocasionado por um triângulo amoroso inesperado: tanto Kóstia quanto Nástia estão apaixonados pelo mesmo rapaz, Serguei Pávlovitch Pavilíkin, o Serioja. O caráter e as intenções desse jovem (que não é rico) não ficam completamente claros, pois, ao mesmo tempo em que se envolve com Kóstia, também pede a mão de Nástia em casamento. Para completar, com o desaparecimento de um antigo anel de família, Serioja se torna o primeiro suspeito, principalmente para Pavla Petróvna, que não o vê com bons olhos. As suspeitas da velha tia geram uma ardorosa discussão entre a família, que acaba de maneira trágica. Com isso, parecem se concretizar as superstições de má sorte associadas ao divã, mas a cena final demonstra, com sutil ironia, que as desgraças da família Gambakov foram ocasionadas unicamente por velhos preconceitos de seus próprios membros.

A inusitada escolha de um divã como narrador(a) e a temática do conto parecem estar relacionadas ao importante papel da literatura francesa na formação de Kuzmin e em seu gosto literário. A narrativa libertina "Le Sopha, conte moral" (1742), de Claude-Prosper Crébillon, é comumente apontada como inspiração para a composição de "O divã de tia Sônia". ${ }^{2}$ De fato, as influências de Kuzmin, "peculiares e profundamente orgânicas", nas palavras de Eikhenbaum, ${ }^{3}$ são majoritariamente estrangeiras, mas sua prosa não deixa de ter também referências russas.

Na presença do divã como elemento central para a narrativa, pode-se notar uma intertextualidade com a obra de Dostoiévski, se pensarmos, por exemplo, em Crime e castigo, romance no qual um sofá é parte primordial do cenário da história. ${ }^{4}$

2 PANOVA, L. A Literary Lion Hidden in lain View: Clues to Mikhail Kuzmin's "Aunt Sonya's Sofa" and "Lecture by Dostoevsky". In: PANOVA, L.; PRATT, S. (orgs.). The Many Facets of Mikhail Kuzmin/ Кузмин многогранный. Bloomington: Slavica, 2011, pp. 06-07.

EIKHEMBAUM, B. op. cit., p. 348.

4 FIELD, A. Mikhail Kuzmin: Notes on Decadent's Prose. Russian Reviews, 22(3), 1963, p.299 apud PANOVA, L. op.cit., p.6. Para além dessas referências, Panova apresenta uma interpretação minuciosa acerca das relações dessa narrativa com a vida e a obra de Liév Tolstói, que certamente merece uma leitura. Resumidamente, a estudiosa vê no conflito de gerações de "O divã de tia Sônia" a dramatização do conflito entre a antiga geração de escritores, encarnada por Tolstói, e a nova geração, a de Kuzmin. 
É de se imaginar quais histórias o sofá de Raskólnikov não contaria, se pudesse... Do ponto de vista estilístico, porém, a prosa de Kuzmin nada tem a ver com a de Dostoiévski ou outro "grande" romancista do século XIX, como Tolstói. O caráter algo anedótico de suas narrativas, a oscilação entre um estilo rebuscado e outro mais coloquial, às vezes até mesmo "desorganizado", aproximaria o escritor de Leskov, também segundo Eikhenbaum. $^{5}$

Ainda sobre possíveis intertextualidades, vale notar que "O divã de tia Sônia" pode ser lido como uma espécie de roman à clef, isto é, uma narrativa que apresenta uma história realmente ocorrida, mas disfarça as identidades das personagens ao trocar seus nomes. Por um lado, a dedicatória de Kuzmin à irmã, Varvara Mochkova, pode apontar para uma possível origem familiar à trama; por outro lado, o personagem Serioja Pavilíkin pode ter sido inspirado em Serguei Pávlovitch Diáguilev - conhecido empresário artístico russo, criador da companhia Ballets Russes, amigo de Kuzmin e notoriamente homossexual -, com quem compartilha nome e patronímico, e em quem o próprio Kuzmin dá a entender, em cartas a amigos, ter se inspirado para compor a personagem. ${ }^{6}$ Essas possibilidades abrem outros leques de interpretação para leitura do conto.

Por fim, é interessante mencionar ainda um detalhe em relação a "O divã de tia Sônia": os desdobramentos do conto dentro da obra do próprio Kuzmin. Nos anos seguintes, encontramos outras narrativas que parecem, direta ou indiretamente, ligadas ao enredo e às personagens desse conto. Em "Café da manhã de caçador" (Охотничий заврак, 1910), temos acesso ao diário da jovem Sônia Nikoláevna, que acaba sendo seduzida por Serguei Pavilíkin, marido de uma de suas amigas mais antigas, Nástia Gambakova. O irmão dessa amiga, Kóstia, também é mencionado nas anotações de Sônia - que tem, aliás, o mesmo nome da pobre tia que faleceu sobre o divã malfadado. Já em "Uma guardiã perigosa" (Опасный страж, 1911), Pavilí-

5 Cf. EIKHENBAUM, B. op. cit., p.350.

6 Cf. PANOVA, L. op. cit., pp. 18-21. 
kin reaparece, agora visitando a família Grodelius e fazendo a corte à jovem Vera, que chega a se tornar sua noiva. A mãe da moça, porém, acaba desfazendo o noivado ao ter acesso a uma carta comprometedora de Serioja ao amigo Kóstia Gambakov. ${ }^{7}$ Tudo isso parece indicar certo apreço de Kuzmin por essas personagens e pelos temas que elas trazem.

Reconhecido poeta da Era de Prata, Kuzmin causou sensação já com a publicação de seus primeiros versos, nos anos 1900. Ao se aventurar na prosa pouco tempo depois, a repercussão não foi a mesma. Em sua estreia como prosador, Kuzmin trouxe o tema da homossexualidade para o centro da história: a novela Asas (1906) é uma narrativa de formação que apresenta a "saída do armário" do jovem Vânia Smúrov. Em textos posteriores, como "O divã de tia Sônia", o tema volta a aparecer, fazendo com que Kuzmin se torne o primeiro escritor russo a tratar da homossexualidade de forma aberta e central em seus textos, e foi essa escolha que parece ter limitado tanto a leitura quanto a recepção de sua obra. Apesar da acolhida relativamente fria, uma vez adentrado o mundo da prosa, Kuzmin não voltou atrás: entre 1910 e 1915, o escritor lançou pelo menos cinco livros de contos, sem contar os publicados em jornais e revistas, além de peças teatrais, porém, sem nunca deixar de lado a poesia, que acabaria por se tornar para sempre o seu "carro chefe", por assim dizer.

É interessante observar que nem todos os textos em prosa de Kuzmin tratam da homossexualidade, há também narrativas históricas que parecem ter recebido um pouco mais de atenção. Assim, parece ficar evidente que essa recepção um tanto fria está muito mais associada à temática do texto do que ao estilo em si ou a algum juízo de valor estético - o próprio Eikhenbaum, embora chame seu ensaio de "Da prosa de M. Kuzmin" e reconheça os valores e inovações das narrativas do escritor, traz como exemplo apenas títulos que não tratam da sexualidade das personagens.

7 Além desses contos, Panova apresenta outros que parecem ter uma relação indireta com "O divã de tia Sônia". Cf. PANOVA, L. op. cit., pp.33-37. 
Durante o regime soviético, a obra de Kuzmin, de maneira geral, foi pouco a pouco relegada ao esquecimento. Ainda em vida, o próprio poeta deixou de ver suas obras publicadas e passou a viver basicamente das traduções que fazia, até falecer de pneumonia em 1936. Foi somente nos anos 1990 que suas obras tornaram a ser editadas. Ainda assim, a poesia continuou sobreposta à prosa, que, ainda hoje, nos anos 2020, carece de uma edição crítica detalhada.

Portanto, mesmo décadas mais tarde, a frase de Eikhenbaum que nos serve de epígrafe continua atual: "A prosa de Kuzmin ainda não entrou em uso - tanto mais interessante falar sobre ela". E é tanto mais interessante falar de Kuzmin e de sua prosa quando o fazemos despidos de preconceitos.

\section{Da tradução}

A presente tradução foi feita a partir do original em russo “Кушетка тёти Сони", publicado originalmente na Revista Vesý $\left(\mathrm{N}^{\circ} 10\right.$, julho de 1907) e posteriormente em Primeiro Livro de Contos (1910). O texto está disponível online (vide referências bibliográficas). Como texto de referência e apoio, foi usada a tradução em inglês de Michael Green, "Aunt Sonya's Sofa" (1997). O cotejo do texto foi realizado em três encontros com Ekaterina Vólkova Américo, cujos comentários e observações foram de grande valia para a formulação da versão final da tradução.

A falta de edições comentadas das obras completas de Kuzmin em geral, de sua prosa principalmente, trouxe alguma dificuldade na elaboração das notas de rodapé. O encontro com o artigo "A Literary Lion Hidden in lain View: Clues to Mikhail Kuzmin's 'Aunt Sonya's Sofa' and 'Lecture by Dostoevsky', de Lada Panova (2011), foi essencial para a verificação de informações, a confirmação de suspeitas e o acréscimo de novas informações.

Dentre os desafios para a tradução destaca-se o próprio estilo de Kuzmin, que mescla sua familiaridade com a poesia com 
trechos mais coloquiais. Há ainda as sutilezas e os subentendidos do texto, também típicos de Kuzmin, que parece não contar a história por inteiro, como se quem lesse tivesse (ou devesse ter) algum conhecimento prévio do que se está contando. A primeira e principal dificuldade, porém, foi a escolha do termo que seria usado já no título: "divã".

Em russo, o título nos apresenta a narradora e personagem principal da história: "кушетка", termo derivado do francês couchette, que se refere a uma espécie de sofá. $O$ aspecto mais importante é que a palavra, em russo, é feminina (como já observado) e, por isso, Kuzmin dá ao móvel uma voz feminina, perceptível no texto original nas formas adjetivas e nas desinências verbais no pretérito, que, em russo, indicam o gênero do sujeito em sua forma singular. Dentre as opções em português para a tradução, não encontrei alguma que fosse feminina.

Poderia ser usado o termo chaise lounge, mas este pediria uma nota de rodapé logo no título, além de não ter a naturalidade de "кушетка" - uma palavra claramente russificada. Outra opção seria "espreguiçadeira", mas esta, ainda que seja usada desde fins do século XIX, poderia trazer uma primeira impressão quase tropical de uma tia Sônia deitada languidamente à beira de uma piscina. Nessa mesma linha de raciocínio, "namoradeira" também não me pareceu uma escolha tão acertada, pois levaria o leitor a pensar antes que o conto é sobre uma mocinha que gosta de namorar (preferencialmente na janela), do que sobre um item de mobília antiga. Restavam, então, as palavras masculinas: "canapé" ou "divã". Como a primeira também poderia causar uma primeira leitura equivocada, já que aos olhos modernos "canapé" remete antes a pequenos aperitivos do que a uma espécie de sofá, acabei optando por "divã".

Em um primeiro momento, pareceu-me que seria necessário sacrificar a voz feminina original, já que "o" divã passaria a ser o narrador da história. Foi durante o cotejo que a questão reapareceu e Ekaterina Vólkova observou que poderiam ser feitas pequenas adaptações que indicassem o gênero da narradora. Assim, sempre que possível, optei por locuções verbais 
ao invés do verbo unicamente: no lugar de "revestiram-me", "fui revestida", por exemplo. Com essas modificações, o conto retomou sua narradora.

É curiosa a relação que estabelecemos com as palavras em idiomas como o português e o russo, que atribuem gêneros a todas elas, ainda que se refiram a objetos inanimados. Com isso, cabe a quem fizer a leitura do conto lidar com o estranhamento e aceitar que "o" divã anunciado no título é, na verdade, "a" divã. Essa escolha traz à tradução uma diferença em relação ao texto-fonte, onde esse estranhamento entre o gênero da palavra e sua identidade de gênero, por assim dizer, não se dá, já que "кушетка" é uma palavra feminina, como já pontuado.

Em se tratando de um texto que aborda de forma tão central a sexualidade das personagens, não deixa de ser um detalhe interessante que a voz narrativa subverta a gramática do português, que atribui (ao acaso) gênero às palavras - o que, em certa medida, influencia nossa imaginação já que podemos, a partir disso, criar possíveis identidades de gênero para toda sorte de objetos. Essa escolha se torna um ganho para a tradução, já que acaba por humanizar ainda mais "a" divã, que não só pensa, interpreta e julga o que se passa ao redor, como também tem uma identidade de gênero própria e inesperada, indo contra a lógica gramatical e, assim, abrindo também outras camadas de leitura e interpretação para o conto.

\section{Referências bibliográficas}

EIKHEMBAUM, Boris. O прозе M. Кузмина [Da prosa de M. Kuzmin]. In: EIKHEMBAUM, Boris. О литературе [Da literatura]. Moscou: Sov. Pissátel', 1987[1920], pp. 348-351. Disponível em: http://philologos.narod.ru/eichenbaum/eich_kuzmin.htm Acesso em 28 set. 2021.

KUZMIN, Mikhail. Aunt Sonya's Sofa. Trad. Michael Green. In: MOSS, Kevin (org.). Out of the blue - Russia's Hidden Gay Literature. São Francisco: Gay Sunsbine Press, 1997, pp. 69-78.

KUZMIN, Mikhail. Кушетка тети Сони [O divã de tia Sônia]. 
In: KUZMIN, Mikhail. Первая книга рассказов [Primeiro Livro de Contos]. Moscou: Skorpion, 1910, pp. 157-178. Disponível em: http://az.lib.ru/k/kuzmin_m_a/text_6_kushetka_teti_ soni.shtml Acesso em 28 set. 2021.

PANOVA, Lada. A Literary Lion Hidden in plain View: Clues to Mikhail Kuzmin's "Aunt Sonya's Sofa" and "Lecture by Dostoevsky". In: PANOVA, Lada; PRATT, Sarah (orgs.). The Many Facets of Mikhail Kuzmin/ Кузмин многогранный. Bloomington: Slavica, 2011, pp. 89-139 [1-61 na versão online]. Disponível em: https://www.academia.edu/23158324/A_Literary_Lion_ Hidden_in_Plain_View_Clues_to_Mikhail_Kuzmin_s_Aunt_ Sonya_s_Sofa_and_Lecture_by_Dostoevsky_ Acesso em 28 set. 2021. 


\section{O divã de tia Sônia ${ }^{8}$}

À minha irmã V. A. Mochkova ${ }^{9}$

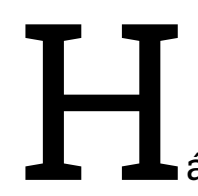

á tanto tempo estou aqui esquecida no depósito, em meio a velhos trastes, que já quase perdi as lembranças de minha mocidade, quando o turco com seu cachimbo e a pastora com um cãozinho caçando pulgas, de pata traseira erguida, bordados em minhas costas, brilhavam em cores vivas, amarelo, rosa e azul-claro, sem estarem cobertos de poeira e desvanecendo; e agora o que mais me ocupa são os eventos dos quais fui testemunha, antes de cair novamente em esquecimento - desta vez irremediável, por certo. Fui revestida com um novo material sedoso, cor de marsala, e, tendo me colocado na antessala, jogaram em meu braço um xale de rosas rutilantes, como se alguma beldade, dos tempos de minha juventude, o tivesse deixado ali subitamente, pega de surpresa em um terno encontro. ${ }^{10} \mathrm{~A}$ propósito, esse xale ficava sempre nessa mesma posição, e quando ou o general ou sua irmã, tia Pavla, mudavam-no de lugar, Kóstia,11 que arranjava a sala a seu gosto, trazia de volta o suave tecido multicolor àquele as-

8 "Кушетка тети Сони", traduzido a partir do original presente em KUZMIN, М. Первая книга рассказов [Primeiro Livro de Contos]. Moscou: Skorpion, 1910, pp. 157-178, disponível online. Embora o título em português referencie um objeto gramaticalmente masculino, sua voz narrativa é feminina. Em russo, a palavra, de origem francesa, é feminina ("кушетка"). Cf. "Nota introdutória" que precede esta tradução.

9 Em solteira, Varvara A. Kuzmina (1857-1922); Mochkova em segundas núpcias com Porfiri S. Mochkov. Foi casada primeiramente com Abram lá. Auslender, que veio a morrer exilado na Sibéria, em 1887. Era mãe do escritor Serguei A. Auslender (1886-1937). Na primeira edição do conto, na Revista Vesý (№ 10, julho 1907), a dedicatória era: "Esta história verdadeira dedico à minha irmãn. (N.T.)

10 Segundo Lada Panova (2011, p.27), este "terno encontro" faz referência ao poema "A Flor" (1828), de Aleksandr Púchkin. (N. T.)

11 Diminutivo de Konstantin. (N.T.) 
pecto estático, de rebuscada negligência. Tia Pavla protestara contra minha retirada do depósito, dizendo que fora em mim que morrera a pobre Sophie, ${ }^{12}$ que por minha causa fora desfeito o casamento de alguém, que eu trazia má sorte à família, mas me defenderam, não somente Kóstia e seus companheiros estudantes e os rapazes, mas também o próprio general:

- São preconceitos seus, Pavla Petróvna! Mesmo que tivesse alguma magia nessa quinquilharia, depois de sessenta anos no depósito, há de ter se esgotado por completo; e depois, ela está tão na passagem que não daria na veneta de ninguém morrer aqui, nem fazer algum pedido de casamento!

Embora não me fosse muito lisonjeira a denominação de "quinquilharia", e o general não fosse lá muito perspicaz, mesmo assim acabei me instalando na antessala com papel de parede esverdeado, tendo defronte uma garrafa de porcelana sobre um pires, e acima desta um velho espelho redondo, que refletia vagamente minhas raras visitas. Com o general Gambakov, além de sua irmã Pavla e do filho Kóstia, vivia ainda sua filha, Nástia, ${ }^{13}$ aluna de instituto. ${ }^{14}$

O cômodo vizinho, voltado para o oeste, deixava escapar até minha antessala longos raios de sol poente, incidindo sobre o xale de rosas, que então brilhava e cintilava com redobrado encanto. Nesse momento, os raios de sol recaíam sobre o rosto e o vestido de Nástia, sentada em mim, e parecendo tão delicadinha que era até estranho não se ver esses mesmos raios de sol através dela, incidindo sobre seu interlocutor, como se sua figura não fosse obstáculo suficiente para a luz rosada do sol. Ela falava com o irmão a respeito de um pretenso espetáculo

12 Versão afrancesada de Sófia, cujo diminutivo em russo é Sônia. (N.T.)

13 Diminutivo de Anastassia; mais adiante, a personagem é referida por outro diminutivo: "Nastássia". (N.T.)

14 Instituto, neste contexto, são as escolas superiores para moças nobres, surgidas no fim do século XIX na Rússia imperial. (N.T.) 
para as festas de Natal, ${ }^{15}$ para o qual haviam sugerido um ato de Ester, ${ }^{16}$ mas parecia que os pensamentos da moça estavam distantes do assunto da conversa. Kóstia observou:

- Acho que Serioja ${ }^{17}$ também poderia representar algo para nós: ele tem uma dicção bastante boa.

- Mas, como? Serguei Pávlovitch seria uma de minhas servas, uma jovem israelita?

- Para quê? Não suporto travesti ${ }^{18}$ embora fossem lhe cair bem roupas de mulher.

- Então quem ele interpretaria?

Entendi que falavam de Serguei Pávlovitch Pavilíkin, ${ }^{19} \mathrm{com}-$ panheiro do jovem Gambakov. A mim ele sempre parecera um menino insignificante, embora muito bonito. Os cabelos escuros cortados curtos deixavam seu rosto redondo, sem cor, ainda mais cheio; tinha uma bonita boca e grandes olhos cinza-claros. Sua alta estatura suavizava certa corpulência, porém ele era bem pesado, sempre se refestelava em mim e deixava-me coberta com as cinzas de seus cigarrinhos que fumava a todo instante em uma piteira muito longa, e suas conversas eram as mais vazias. Frequentava nossa casa todos os dias, apesar do descontentamento de Pavla Petróvna, que não gostava dele.

A mocinha, depois de um tempo calada, começou com hesitação:

- Você conhece bem o Pavilíkin, Kóstia?

- Que pergunta! É o meu melhor amigo!

15 Em russo, sviátki, período que vai de 06 a 19 de janeiro no calendário juliano, usado pela Igreja Ortodoxa (equivalente a 25 de dezembro a 06 de janeiro, no calendário gregoriano, ou seja, entre o dia de Natal e a Noite de Reis na tradição católica). (N.T.)

16 Personagem bíblica do Antigo Testamento. Tornou-se imperatriz da Pérsia ao desposar Assuero e assim pôde intervir a favor de seu povo, os judeus. Conforme aponta Panova (2011, p.32), é provável que a referência, aqui, seja a tragédia francesa Ester (1689), de Jean Racine (1639-1699). (N.T.)

17 Diminutivo de Serguei. (N.T.)

18 Em francês no original, fazendo referência ao ato de travestimento. (N.T.)

19 Conforme sugere Panova (2011, p.19), este sobrenome foi criado por Kuzmin e parece ser derivado de "povilika", isto é, "cuscuta", termo genérico dado a certas plantas trepadeiras parasitas. (N.T.) 
-É?.. Então faz tempo que vocês são amigos?

- Desde este ano, quando entrei na universidade. Mas isso quer dizer alguma coisa?

- Não, perguntei só para saber...

- Por que está interessada em nossa amizade?

- Queria saber se ele é de confiança... eu queria...

Kóstia a interrompeu com uma risada:

- Depende do que se trata! Se é questão financeira, não recomendo!.. Bem, ele é um bom camarada e não é avarento, quando tem dinheiro, mas é pobre...

Nástia, depois de um tempo calada, disse:

- Não, não é nada disso, mas e em questão sentimental, afetiva?

- Que bobagem! O que andam enfiando na cabeça de vocês nesses institutos? Como é que eu vou saber!.. Está apaixonada pelo Serioja ou quê?

Sem responder, a mocinha continuou:

- Tenho um pedido a fazer: você atende?

- Em relação a Serguei Pávlovitch?

- Talvez.

- Tudo bem, mas fique sabendo que ele não é de perder tempo com mocinhas de instituto.

- Não, Kóstia, você tem que prometer!..

- Está bem, já disse! E então?

- À noite te conto - disse Nástia, olhando para os olhos fugidios do irmão, castanhos, faiscantes, como os dela.

- À noite, então, à noite - repetiu levianamente o rapaz, levantando-se e ajeitando o xale de rosas que a jovem liberara ao também se levantar.

Mas os raios do sol poente não brincaram nas suaves rosas, pois Nástia, indo para o cômodo vizinho, ficou junto à janela, tão impenetrável para a rosada luz do sol quanto antes, e assim ficou, olhando para a rua coberta de neve, enquanto não ligavam a eletricidade. 
Hoje não tive um minuto de sossego: uma correria pela minha sala! E para que inventam de fazer esses espetáculos? Não entendo! Um enxame de mocinhas, de rapazes; andavam azafamados, gritavam, corriam, chamaram uns mujiques para serrar não sei o quê; levaram a mobília, as almofadas, os tecidos; que bom que da antessala não pegaram nada nem levaram embora o meu xale! Por fim, tudo se aquietou e ao longe começaram a tocar piano. O general e Pavla Petróvna entraram com cuidado e sentaram-se lado a lado; a solteirona dizia:

- Vai ser a desgraça da família, se ela se apaixonar por ele. Imagine, um perfeito rapazola e de que espécie: sem nome, sem condições, não tem nada de especial!..

- Acho que você exagera demais; eu não notei nada...

- E os homens lá notam coisas desse tipo? Eu, em todo caso, serei contra até o fim!

- Acho que a questão não chegará ao ponto de você precisar ser contra.

- Ele é absolutamente imoral: sabe o que dizem dele? Tenho certeza de que é ele quem está estragando o Kóstia. Nástia é uma criança, não entende de nada - inflamava-se a velha dama.

- Ora, mana, de quem é que não falam? Se você soubesse o que andam falando do Kóstia! E nem eu mesmo sei se essas histórias não são, em parte, verdadeiras. Isso não me diz respeito. A única coisa que protege das fofocas é a idade, como a nossa!..

Pavla Petróvna corou por completo e observou apenas:

- Faça como quiser, eu avisei, e hei de ser mais severa: Nástia é como uma filha para mim!

Nisso entrou Nástia, já com seu figurino: era azul-claro com listras amarelas e um turbante amarelo.

- Papai - disse, apressada, ao general -, por que o senhor não está assistindo ao ensaio? - e, sem esperar pela resposta, continuou: - Você não emprestaria o seu anel ao nosso rei? Aquele com a esmeralda enorme! 
- Este aqui? - perguntou o velho, surpreso, mostrando uma peça antiga e rara, um anel com uma esmeralda escura, do tamanho de uma groselha graúda. ${ }^{20}$

- Sim, este! - respondeu a mocinha, despreocupada.

- Nástia, você não faz ideia do que está pedindo! - interveio a tia. - Emprestar um anel de família, do qual Maksim não se separa nunca, para essa sua baderna, para vocês perderem na mesma hora? Você sabe que seu pai não o tira nunca!

- Uma ou duas vezes, só; mesmo que caísse do dedo, do quarto não iria sumir.

- Não, Maksim, eu decididamente não permito que você o tire!

- Está vendo, tia Pavla não me deixa! - disse o general com um riso embaraçado.

Nástia saiu desgostosa sem o anel, enquanto Pavla Petróvna pôs-se a reconfortar o irmão, que estava com pena da filha entristecida.

Outra vez barulho, corre-corre, troca de roupa, despedidas.

O senhor Pavilíkin ficou em nossa casa por muito tempo. Quando ele e Kóstia entraram em meu aposento, já era perto das quatro horas da manhã. Detiveram-se e deram um beijo de despedida. Serguei Pávlovitch dizia, embaraçado:

- Você não pode nem imaginar, Kóstia, como estou contente! Mas me incomoda tanto que isso tenha acontecido justamente hoje, depois de você ter me emprestado aquele dinheiro! Deus sabe que bobagens você pode pensar...

Kóstia, pálido e feliz, com os cabelos amarfanhados, outra vez o beijou, dizendo:

- Não vou pensar nada, você é mesmo uma figura! Foi só coincidência, uma coisa como outra qualquer.

- Sim, mas é tão embaraçoso, tão embaraçoso...

- Deixe disso, por favor, na primavera você devolve...

- Precisava tanto desses 600 rublos...

200 anel de Gambakov, como observa Panova (2011, p.31), faz referência ao lendário anel de esmeralda do tirano grego Polícrates (c.574-522), símbolo tanto de sua boa fortuna quanto de sua desdita. (N.T.) 
Kóstia já se calara. Ali, parado, ele disse:

- Então até logo. Amanhã vamos juntos ver a Manon. ${ }^{21}$

- Vamos, sim!

- E não vai com o Piétia Klímov?

- Oh, tempi passati! ${ }^{22}$ Até logo!

- Feche a porta e não faça barulho quando for passar pelo quarto de tia Pavla: ela não te viu voltar e não morre de amores por você. Até logo!

Os rapazes se despediram mais uma vez; era, como eu já disse, perto das quatro horas da manhã.

Sem tirar o gorro de pele enfeitado de rosas depois do passeio, Nástia sentou-se na ponta de uma cadeira, enquanto seu cavaleiro continuava a andar pelo quarto com as bochechas ligeiramente coradas de frio. A moça falava com suavidade e alegria, mas ouvia-se um quê de preocupação naquele chilrear.

- Que ótimo passeio fizemos! É tão bom: frio e sol! Adoro passear pela margem do rio!..

- Pois é.

- Gosto imensamente de andar a cavalo, ainda mais pela margem alta; no verão, passo o dia todo nesses passeios. O senhor não esteve conosco em Sviataia Krutcha? ${ }^{23}$

- Não. Eu prefiro os automóveis.

- Que péssimo gosto o seu... Pois o senhor já conhece Sviataia Krutcha, Aleksieévskoe e Lgóvka, tudo isso é meu, só meu; sou uma noiva muito rica. E depois, titia Pavla Petróvna fará de mim sua única herdeira. Está vendo só? Recomendo que o

21 Título de duas óperas: Manon (1884), uma das composições mais conhecidas de Julles Massenet (1842-1912); e Manon Lescault (1893), um dos primeiros trabalhos operísticos de Giacomo Puccini (1858-1924). Ambas foram inspiradas no romance Historie du Chevalier des Grivex et de Manon Lescaut (1731), do abade Prévost (1697-1763). (N.T.)

22 "Tempos passados", em italiano no original. (N.T.)

23 Sviataia Krutcha, assim como Aleksieévskoe e Lgóvka, presume-se, são propriedades da família Gambakov, a serem herdadas por Nástia. (N.T.) 
senhor pense um pouco.

- Seria dar um passo maior que a perna, não?

- De onde o senhor tira essas frases de caixeiro?

Serioja deu de ombros e continuou andando, sem parar. A mocinha bem que tentou, uma ou duas vezes, recomeçar o chilreio, cada vez mais e mais curto, como um brinquedo quebrado, enfim calou-se e, quando tornou a falar, sua voz era já abafada e triste. Sem tirar o gorro, sentou-se mais para trás e começou a dizer, na sala que escurecera, como que se queixando para si mesma:

- Quanto tempo faz do nosso espetáculo!.. Lembra? A sua entrada... Muita coisa mudou desde então! O senhor já não é o mesmo, nem eu, nem ninguém... Eu ainda o conhecia pouco naquele tempo. O senhor não pode imaginar como eu o entendo muito melhor que o Kóstia! Não acredita? Por que se faz de tolo? Ficaria satisfeito se eu mesma dissesse que é considerado humilhante uma mulher falar primeiro? O senhor me atormenta, Serguei Pávlovitch!

- É um tremendo exagero de sua parte, Nastássia Maksímova: tanto da minha falta de perspicácia, quanto do meu amor-próprio e, talvez, até de sua relação comigo...

Ela levantou-se e disse, inaudível:

- É mesmo? Pode ser...

- Vai se retirar? - eriçou-se ele.

- Sim, preciso mudar de roupa para o almoço. O senhor almoça conosco?

- Sim, almoço.

- Com o Kóstia?

- Não. Por quê?

Ela ainda não saíra, estava de pé junto a mesa de revistas.

- O senhor vai vê-lo?

- Não, estou de saída.

- É? Então, até logo! E eu amo o senhor, pronto! - acrescentou ela, de repente, virando-se para outro lado. Vendo que ele estava calado na escuridão, que escondia seu rosto, ela rapida- 
mente pronunciou, como que com um riso na voz: - E então? Está satisfeito?

- Por acaso a senhora acha que essa é a palavra adequada? - disse ele, curvando-se para a mão dela.

- Até logo... Agora, vá - sentenciou ela, passando para o cômodo ao lado. Serioja acendeu a luz e foi para o quarto de Kóstia, cantarolando alegremente.

O general entrou tomado de grande agitação, segurando um jornal nas mãos; Pavla Petróvna, farfalhando o negro vestido de seda, o seguia a passos rápidos.

- Acalme-se, Maksim! Agora isso acontece com tanta frequência que a gente quase se acostuma. Claro, é horrível, mas o que fazer? Não se pode remar contra a maré, como dizem...

- Não, Pavla, não consigo me conformar: só o quepe sobrou e coberto de sangue, com os miolos, uma pasta na parede. Pobre Liév Ivánovitch!

- Não pense nisso, meu irmão! Amanhã mandamos rezar uma missa em Udiély. Não pense nisso, cuide-se: você mesmo tem sua filha e seu filho.

O general, vermelho, apeou-se em mim, deixou cair o jornal; a velha dama recolheu-o depressa e colocou-o longe do irmão e logo pôs-se a falar de outro assunto:

- Então, encontrou o anel?

O general tornou a ficar inquieto:

- Não, não! E ainda mais essa para me preocupar.

- Quando o viu pela última vez?

- Hoje de manhã mesmo, aqui neste divã, eu o mostrei a Serguei Pávlovitch: ele ficou muito interessado... Depois caí no sono, quando acordei, lembro que o anel já tinha sumido.

- Você o tirou?

- Tirei...

- Não foi nada sensato de sua parte! Além do valor financei- 
ro, é um objeto inestimável, de família.

- É um perfeito prenúncio de desgraças.

- Esperemos que a morte de Liév Ivánovitch seja toda a desgraça e que não haja nada mais.

O general pôs-se a suspirar outra vez. Pavla Petróvna não se conteve e recomeçou:

- Será que Pavilíkin não o pegou? É de se esperar!

- Para quê? Para ver melhor? Ele mesmo o viu muito bem e perguntou quanto dariam por ele no antiquário e tudo o mais.

- Pode ser que pegou por pegar.

- Ou seja, surrupiou, você acha?

Pavla Petróvna não teve tempo de responder, pois Nástia apareceu na conversa, entrando, veloz e agitada, na sala.

- Papai! - disse em voz alta - Serguei Pávlovitch está pedindo a minha mão; espero que o senhor não seja contra!

- Não agora, agora não! - o general começou a agitar as mãos na direção dela.

- Por quê? Por que deixar para depois? Você o conhece bem o suficiente - disse Nástia e corou.

Pavla Petróvna levantou-se, dizendo:

- Eu também tenho voz e protesto veementemente contra essa união, mas em todo caso exijo que a resposta seja adiada enquanto não for encontrado o anel de Maksim.

- O que o anel de papai tem a ver com o meu noivo? - perguntou com soberba a jovem.

- Achamos que o anel está com Serguei Pávlovitch.

- Acham que foi ele quem roubou?

- Sim, algo assim.

Nástia voltou-se para o general e, sem responder à tia, disse:

- Você também acredita nessa invencionice?

O pai calou, ainda mais vermelho.

A jovem dirigiu-se a Pavla:

- Por que está se colocando entre nós? A senhora odeia o Serioja, o Serguei Pávlovitch, e inventa todo tipo de absurdo! 
Fica fazendo meu pai e Kóstia brigarem. O que quer de nós?

- Nastássia, não seja insolente, não se atreva! - disse o pai, sem ar.

Nástia não lhe deu ouvidos.

- Por que tanta raiva? Por que você não pode esperar até que se esclareça essa história? É questão de princípios, entende?

- Eu entendo que não devem nem suspeitar de meu noivo em uma situação dessas! - gritou Nástia; o general continuava sentado, em silêncio, cada vez mais vermelho.

- Está com medo da verdade?

- Só pode haver uma verdade, e eu sei qual é. E aconselho que não se oponha ao nosso casamento: será pior para a senhora!

- Você acha?

- Eu sei!

Pavla olhou fixamente para ela.

- Há necessidade de tanta pressa?

- Quanta vulgaridade! Kóstia! - Nástia, lançando-se em direção do estudante que entrava - Kóstia, querido, seja nosso juiz! Serguei Pávlovitch está pedindo a minha mão e nosso pai, por total influência de tia Pavla, não quer concordar enquanto não se descubra onde foi parar o anel dele.

- Como é? Que patifaria! Estão acusando Pavilíkin de roubo?

- Sim! - disse maldosamente a velha dama. - Você, é claro, vai interceder por ele, vai comprar o anel de volta. E estou sabendo também de umas coisinhas a seu respeito! Do meu quarto dá para ouvir as portas rangendo quando entra o seu amiguinho e sobre o que vocês conversam. Fique grato por eu me manter calada!

Nunca em minha vida eu ouvira um escândalo daqueles, quantos impropérios. Kóstia sacudia o punho, urrava; Pavla gritava que se respeitassem os mais velhos; Nástia falava histericamente... De repente, porém, calaram-se, pois todas as vozes, gritos e ruídos foram cobertos por um som inumano, vindo subitamente do general, até então em silêncio, que se erguia. Depois ele caiu pesadamente, vermelho-azulado, e co- 
meçou a arquejar. Pavla precipitou-se sobre ele:

- O que há com você? Maksim, Maksim?

O general arquejava, revirando os olhos, azul.

- Água! Água! Ele está morrendo, é um acesso! - sussurrava a tia, mas Nástia afastou-a com as seguintes palavras:

- Deixe, eu mesma solto o colarinho! - e pôs-se de joelhos diante de mim.

Até mesmo à antessala chegavam o cheiro do incenso e os cânticos das exéquias do velho general. Às vezes, parecia que era por mim que entoavam aqueles cantos. Ah, eu não estava tão longe da verdade!

Quando os rapazes entraram, Pavilíkin continuava uma conversa já iniciada:

- E eis que hoje recebi de Pavla Petróvna o seguinte bilhete - e tirando do bolso uma carta, leu em voz alta:

"Estimado senhor Serguei Pávlovitch! Por razões que, supõe-se, não há necessidade de explicar ao senhor, considero que vossas visitas, nestes dias tão difíceis para nossa família, sejam desnecessárias e, espero eu, o senhor não deixará de corroborar vosso comportamento com nosso comum desejo. O futuro dará a oportunidade de retomarmos as antigas relações, mas posso afirmar ao senhor que Anastassia Maksímova, minha sobrinha, nesta situação, é plenamente solidária a mim. Respeitosamente etc."

Ele olhou com ar de interrogação para Kóstia, que lhe observou:

- Sabe, titia não deixa de ter razão, a seu modo, e eu não sei o que minha irmã vai lhe responder.

- Mas, você há de concordar, são razões ínfimas!..

- Quer dizer a morte de papai?

- Sim, uma vez que eu não tenho culpa disso!

- Claro... Eu li há pouco tempo uma história das Mil e Uma Noites, onde um rapaz jogava fora caroços de tâmaras, uma 
ação absolutamente inocente, e, quando um desses caroços caiu no olho do filho de um Gênio, ele acabou atraindo para si uma série de infortúnios. ${ }^{24}$ Quem pode prever de antemão as consequências das pequenas coisas?

- Mas nós ainda vamos nos ver?

- Ah, sim, sem dúvidas! Não vou mais morar com minha família e fico sempre feliz em ver você. Isso é mais duradouro que a paixão de uma aluna de instituto.

- E não tem medo dos caroços de tâmara?

- Precisamente...

Serioja abraçou o jovem Gambakov, e eles saíram juntos da sala. Não vi mais Pavilíkin, como também em geral pouco vi as pessoas que estiveram comigo em meus últimos dias de estima.

De manhã cedo, vieram uns mujiques de botas e, perguntando à Pavla Petróvna: "é isso aqui?", prepararam-se para me erguer. $O$ mais velho bem que tentou saber se não havia algo mais para vender, porém, ao receber uma resposta negativa, seguiu com os outros.

Quando me viraram para passar pela porta, alguma coisa bateu no assoalho, já livre dos tapetes por conta da proximidade do verão. Um dos carregadores, pegando o objeto caído, entregou-o à velha dama, dizendo:

- É um anelzinho! A senhora deve ter deixado cair no divã, e aí foi parar atrás do forro.

- Está bem. Agradecida! - disse tia Pavla empalidecendo e, apressando-se em colocar em sua retícula o anel de esmeralda, graúda como uma groselha, saiu da sala.

Recebido em: 15/10/2021

Aceito em: 31/11/2021

24 Trata-se, possivelmente, do conto "0 mercador e o gênio". (N.T.) 